\title{
The Impact of Climate Change, Water Security and the Implications for Agriculture
}

\section{Nathalie Rousset}

\section{(2) OpenEdition}

\section{Journals}

Édition électronique

URL : http://journals.openedition.org/chinaperspectives/1213

DOI : 10.4000/chinaperspectives. 1213

ISSN : 1996-4617

Éditeur

Centre d'étude français sur la Chine contemporaine

\section{Édition imprimée}

Date de publication : 15 janvier 2007

ISSN : 2070-3449

Référence électronique

Nathalie Rousset, «The Impact of Climate Change, Water Security and the Implications for Agriculture », China Perspectives [En ligne], 2007/1 | 2007, mis en ligne le 08 avril 2008, consulté le 10 décembre 2020. URL : http://journals.openedition.org/chinaperspectives/1213; DOI : https://doi.org/ 10.4000/chinaperspectives. 1213 
C

The Impact of Climate Change, Water Security and the

\title{
Implications for Agriculture
}

\author{
The Case of Northern China
}

\section{NATHALIE ROUSSET}

$\mathrm{T}$ he intensification of the greenhouse effect through human activity poses global environmental problems of a kind never previously encountered in history. A potential victim, but also a cause of the current dramatic climatic changes, China must, as a matter of urgency, take stock of the risks it runs and establish workable strategies to respond to the problems. The aim of this article is to highlight the potential impacts of climate change on the water resources and agriculture of northern China ${ }^{(1)}$.

The application of the MAGICC-SCENGEN ${ }^{(2)}$ model to China shows that temperatures could well increase by between $0.6^{\circ} \mathrm{C}$ and $1.3^{\circ} \mathrm{C}$ between now and 2030 and from $1.2^{\circ} \mathrm{C}$ to $2.3^{\circ} \mathrm{C}$ by 2050 . If this happens, the north of the country would warm up more rapidly than the south. The rainfall pattern would also be affected and the model predicts a slight increase over most of the country with a reduction in the central plains (Figure 1).

To analyse the implications of climate change we need to begin with the risks involved in climatic variability and the management of natural resources, and to analyse how the anticipated climate changes might increase those risks. In China, the water resource situation in the northern plains is central to developmental issues. The balance between water availability and water use has already been upset and this trend could be aggravated by climate change. The increasing scarcity of water, together with competition from industry and urban centres, places the capacity of agricultural irrigation under great pressure. Cereal production, a sector heavily dependent on irrigation, is thus faced with an unprecedented challenge.
Figure 1. Variations in temperatures and rainfall in 2030 compared with 1990, scenario $A 1 B$

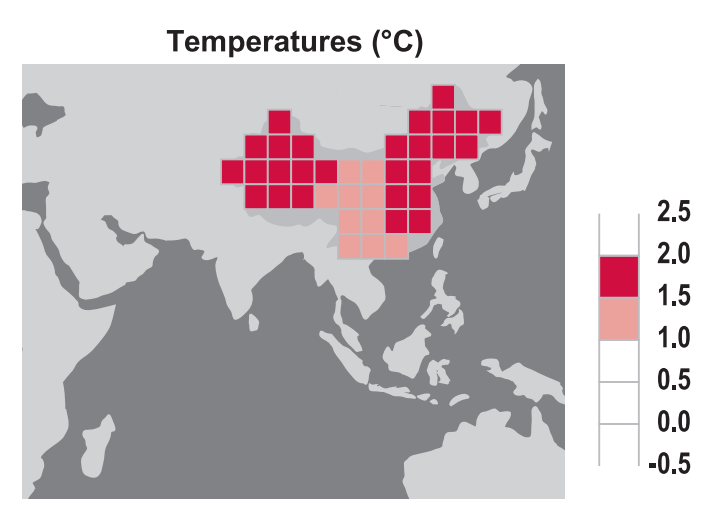

Rainfall (\%)

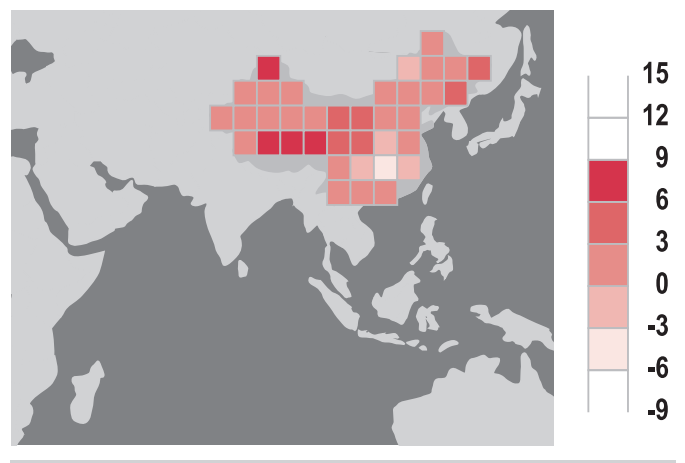

Source: MAGICC-SCENGEN

1. IPCC, Climate Change 2007, The Physical Science Basis, Summary for the Policymakers, Contribution of Working Group I to the Fourth Assessment Report of the Intergovernmental Panel on Climate Change, Geneva, 2007.

2. Mike Hulme et al., Using a Climate Scenario Generator for Vulnerability and Adaptation Assessments: MAGICC \& SCENGEN Version 2.4, Climatic Research Unit, UEA, Norwich, 2000. 


\section{The water challenge in China: shortages in regions and cities}

\section{Limited resources, unevenly distributed and overexploited}

At first glance, China seems to be a country with relatively abundant water resources. Usable resources are estimated at 2,812 billion cubic metres per year, putting China sixth in world ranking. Seen in terms of population, however, available resources are only some 2,200 cubic metres per capita per year, one of the lowest levels in the world, although one that still places China above the threshold of "water stress." ${ }^{(3)}$ But the seriousness of the water situation in China is best illustrated by the large regional disparities. While demand is growing across the whole country, available water supplies in the north (757 cubic metres per head) represent only one quarter of those of the south $(3,208)$, which places the whole of the northern region in a state of water scarcity. Northern China, where $42 \%$ of the population live and, above all, where $60 \%$ of all arable land is located, have only $14 \%$ of China's water resources. Seen in terms of hydrographic basins, the contrasts are even more striking (Graph 1). The rates of resource utilisation in the northern basins are often three or four times those in the south and frequently exceed overexploitation thresholds. In the basin of the Hai River, in particular, these rates exceed $95 \%$.

Despite these limited resources, we are now witnessing a significant increase in total demand, principally from industry and urban centres. Crop irrigation continues to be the heaviest user of water resources accounting for $67 \%$ of the water consumed, followed by industry which now accounts for $21 \%$ of demand ${ }^{(4)}$. Water used by agriculture has, however, only increased marginally since 1980, although China has, for several years, been pursuing its program of food self-sufficiency. On the other hand, in the context of China's substantial economic growth and accelerated industrialisation, use by industry has increased threefold. The growth in domestic use is also due in very large measure to the needs of towns and cities. Consumption grows strongly as urban households, where the middle classes increasingly live, adopt characteristic levels of use.

Despite the shortages, water is used relatively inefficiently. The pollution of most Chinese waterways is also a contributing factor to the scarcity of the resource. According to the SEPA ${ }^{(5)}, 34 \%$ of the waters of the seven main Chinese rivers are heavily polluted. The Pearl River and the Yangtze are generally of good quality, but the same cannot be said of
Graph 1. Water resource usage rates in the principal Chinese water basins
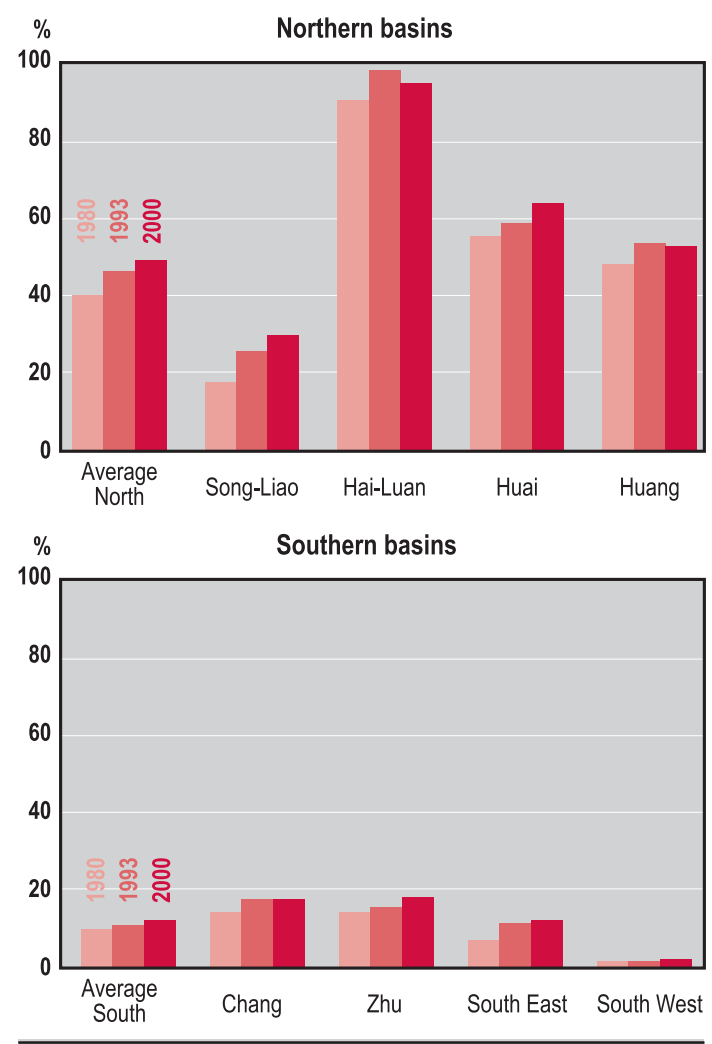

Source: Chinese Statistical Yearbook, 2003

most of the waterways in the north of the country which suffer from chronic pollution, and where the state of the Hai River is particularly alarming.

Water is particularly scarce in the basin of the " $3-\mathrm{H}$ ". This region encompasses the three principal rivers of northern China, the Huanghe (Yellow River) and the Hai and Huai rivers. It includes the cities of Beijing and Tianjin as well as China's main agricultural provinces. The basin of the 3-H, China's "cereal granary", accounts for $39 \%$ of its arable land, is home to 460 million people, and produces one-third

3. The United Nations and the World Bank consider that a country is in "water stress" when the annual available resources per capita are less than or equal to 2000 cubic metres, and in water scarcity when they are less than or equal to 1000 . Below 500 , a country is in absolute water scarcity. These figures include both domestic usage and water used for productive purposes.

4. World Bank, China Agenda for Water Sector Strategy for North China, Main Report, Washington DC, 2002.

5. SEPA (State Environmental Protection Administration), Report on the State of the Environment in China, 2005. 
$\geq$ of its GDP, but has only $10 \%$ of the country's water resources. The World Bank estimated that the region's water deficit in 2000 had already reached 39 billion cubic metres and average availability per head to be only 525 cubic metres per year, well below scarcity levels. Water shortages are also emerging in the rapidly growing urban centres. It is estimated that of China's 600 cities 400 are in water poverty and of the latter, 110 are experiencing serious shortages. They are concentrated principally in the north of the country.

To make up for shortages of surface water, underground sources are tapped more and more frequently in the north and their rates of utilisation are often higher than their rates of replenishment. In 1995, it was estimated that underground water sources met about $60 \%$ of the need in the urban areas of the 3-Hs region, and every year Beijing takes $75 \%$ of its consumption from non-renewable aquifers. As a result of this overuse, the levels of underground reserves have fallen from 50 metres to 90 metres in the Hai river plains and from 100 metres to 300 metres in the Beijing region, resulting in problems of saline intrusion in the reserves near the coast and severe damage to buildings in Beijing, Tianjin and Shanghai.

\section{The effect of worsening drought conditions}

The structural scarcity of water is thus the result of the unequal distribution of water resources between the north and the south, of the size of the population and of the increasing pace of urbanisation and industrialisation. It is also the result of climate trends observed in recent decades. The long-term data show that temperatures have increased steadily since the 1960s resulting in increased evaporation. At the same time, rainfall levels show a downward trend, particularly in the northern plains ${ }^{(6)}$. These changes partly explain the sometimes dramatic decreases in surface flows. A major contributing factor in the water crisis is the impact of drought. Since the 1980s, the frequency, magnitude and length of droughts have been increasing, with severe consequences. China has been seriously affected over the last ten years and the northern plains have experienced seven consecutive years of drought, a record since the establishment of the People's Republic of China. The years 2000, 2002 and 2006 saw the worst droughts for fifty years.

The greater frequency of droughts and increasing water utilisation result in particularly worrying situations such as that of the Yellow River, cradle of the Han civilisation and heartland of the main cereal growing area, which today looks like a "worn out old man." Water flows have been decreasing for
Graph 2. Rainfall and water flow trends in the basin of the Yellow River
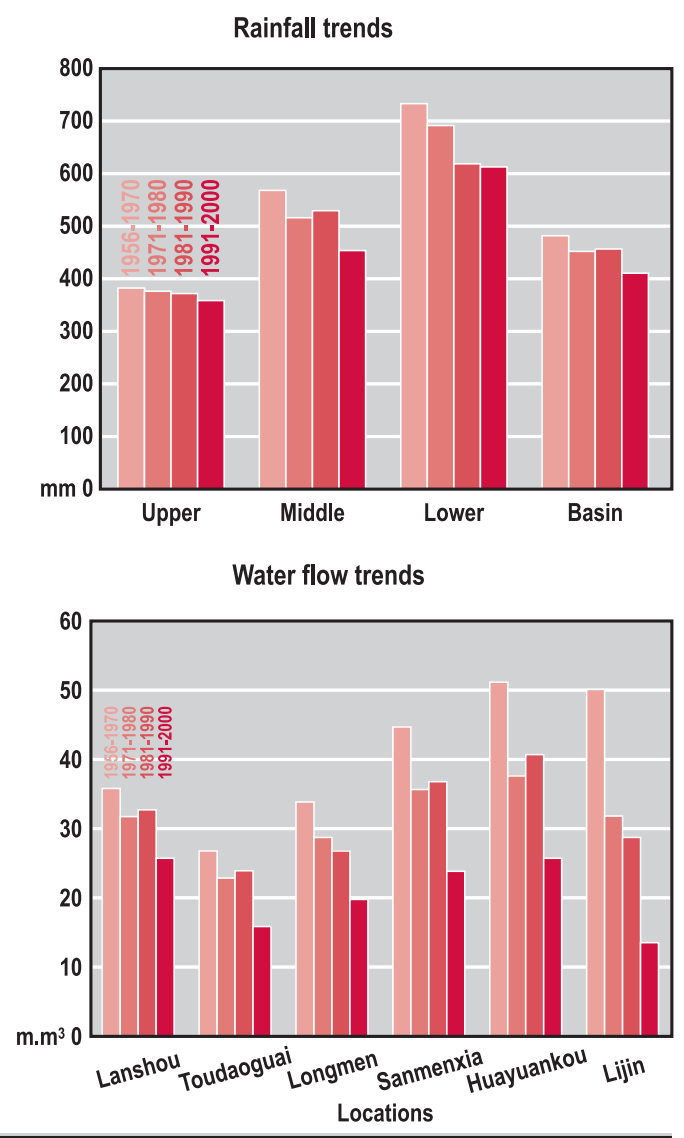

Source: YRCC, 2002

thirty years ${ }^{(7)}$ and every year between 1985 and 2000 the river dried up before reaching the Yellow Sea (Graph 2). The drought periods are getting longer and the geographical area affected is growing: in 1996, for the first time, the waters of the Huanghe (Yellow River) did not reach the province of Shandong. In 1997, the situation was exacerbated by drought and these waters barely reached Hebei province. In that year, the drought lasted 227 days compared with 40 at the beginning of the 1990s a record ${ }^{(8)}$.

Thus, water shortages in north China are alarming and

6. Jianping Yang et al., "Fluctuations of the Semi-Arid Zone in China and Consequences for Society," Climatic Change, 72 (1-2), 2005, pp. 171-188.

7. YRCC (Yellow River Conservancy Commission), Yellow River in the 20th Century, Yellow River Water Utilization Publisher, 2001.

8. Jean-Pierre Cabestan, "Towards a Food Crisis in China and the World," interview with Lester Brown, Perspectives Chinoises, n 18, 1997, p. 1. 
numerous indicators show that the situation has been getting worse over the last twenty years in the wake of economic development, urbanisation and worsening droughts. Water scarcity is especially costly for the country's economic and social development. The drought that struck China in 2002, for example, affected 65 million people and cost US\$1.2 billion ${ }^{(9)}$.

\section{The future to 2030: increased risks due to climate change}

\section{Water shortage trends...}

The problem of water security in the northern regions is a priority developmental concern for China. Analysis of consumption trends and for possibilities of increasing supplies over the coming decades shows that water deficits are going to get worse, and could be exacerbated by climate change. The situation in the northern plains and the future of the 3$\mathrm{H}$ basin give a clear picture of the challenge that China will have to face between 2000 and 2050.

According to World Bank projections ${ }^{(10)}$, the total demand for water in this region will increase by $20 \%$ between 2000 and $2050^{(11)}$, reaching a volume of 200 billion cubic metres. The increase in requirement, particularly pronounced between 2000 and 2020, approximately 7\% each decade, will be due essentially to domestic and industrial needs in the urban areas which are expected to increase by $66 \%$ and $56 \%$ respectively between 2000 and 2020 . On the supply side, the potential for additional capacity is very limited in the basin of the 3-H, all options already being utilised more or less to their maximum. Supply in this region will in all likelihood increase by only ten billion cubic metres between now and 2020 and then stabilise rapidly.

The water supply deficit in the basin of the $3-\mathrm{H}$ is bound to get much worse. Estimated at 39 billion cubic metres in 2000 , it will increase by $25 \%$ by 2020 and by $46 \%$ by 2050 , to reach 57 billion cubic metres. Kaiyuan jieliu, which literally means "open up new sources and economise on use," is a well known saying in the management of water resources in China. The introduction of further measures of adaptation to scarcity would enable a reduction in the gap between needs and availability ${ }^{(12)}$. On the demand side, an increase in the price of water of $10 \%$ per year and a $10 \%$ improvement in irrigation efficiency above the baseline scenario would reduce the water deficit by $14 \%$ in 2020 and by $22 \%$ in 2050 . On the supply side, recycling waste water would further improve the situation by $4 \%$, while the intro-
Graph 3. Supply and demand trends and water deficits in the $3 \mathrm{H}$ basin

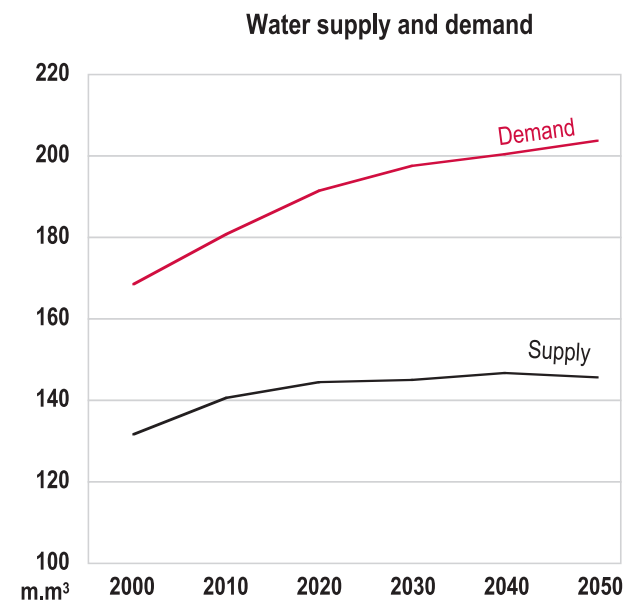

Water deficit under various scenarios

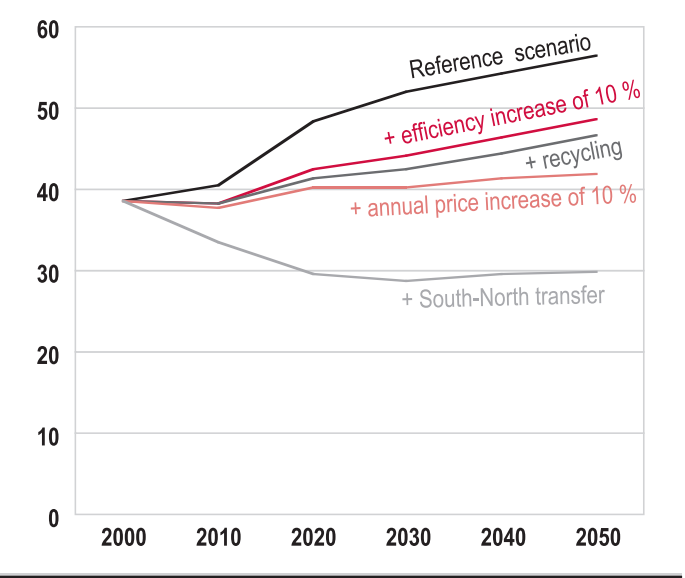

Source: World Bank, 2002.

duction of inter-regional transfers from the south to the north would reduce water deficits by an additional $22 \%$. Taken together, these four measures would therefore reduce the gap between supply and demand by 39\% by 2020 . However, despite the significant effects that such a scenario would entail, water deficits would remain substantial (Graph 3).

9. EM-DAT, The International Disaster Database, http://www.em-dat.net/

10. World Bank, China Agenda for Water Sector Strategy for North China, op. cit..

11. These projections assume an $8 \%$ improvement in irrigation efficiency and a $2 \%$ annual increase in the price of water.

12. World Bank, China Agenda for Water Sector Strategy for North China, op. cit.. 
Table 1. Expected variations in temperature, rainfall, evaporation and water flows in four river basins in northern China

\begin{tabular}{lc|c|c|c|c}
\hline Basins & \multicolumn{1}{|c|}{ Liao } & $\begin{array}{c}\text { Beijing-Tianjin- } \\
\text { Tangshan }\end{array}$ & Huanghe & Huaihe \\
\hline $\begin{array}{l}\text { Climate } \\
\text { scenario }\end{array}$ & $\Delta \mathrm{T}\left({ }^{\circ} \mathrm{C}\right)$ & 1.2 & 1.2 & 1.2 & 1.1 \\
\cline { 2 - 5 } & $\Delta \mathrm{P}(\%)$ & 3.9 & 1.1 & 0.3 & 0.1 \\
\hline $\begin{array}{l}\text { Response } \\
\text { of water } \\
\text { variables }\end{array}$ & $\Delta \mathrm{E}(\%)$ & 1.2 & 3.8 & 2.5 & 3.9 \\
\hline
\end{tabular}

Source: Ying Aixen, Impact of Global Climate Change on China's Water Resources', op. cit.

\section{...exacerbated by climate change}

Water shortage trends in northern China could be made worse by climate change. Changes in temperature and rainfall patterns anticipated by 2030-2050 will alter the timing and magnitude of water flows in rivers, with major implications for water resources and their management.

The adaptability of water resources to climate change depends on their vulnerability and their sensitivity to the changes. Given the amount of water being taken out, the overexploitation of deep aquifers, and the variability of flows, the water supply systems in northern China seem increasingly vulnerable. Thus, there is, generally speaking, little room for manœuvre. The sensitivity of water resources to climate change increases as one moves from the wet south to the semi-arid north: small changes in rainfall or temperature would have major effects on water resources. Model results show that water flows will decrease significantly in many northern basins and increase in the north-east and the south ${ }^{(13)}$. The basins of the Huai and Huang rivers seem particularly at risk as flow reductions of $11 \%$ and $6 \%$ respectively are expected. The Beijing-Tianjin-Tangshan region, already severely affected by limited water availability, would also not be spared (Table 1).

In addition to these average flow variations, climate change will increase the frequency and magnitude of extreme meteorological events such as droughts. Changes in drought patterns are a key aspect of risk assessment since such events are already having severe socio-economic impacts. In the $3 \mathrm{H}$ basin, drought years lead to increased water deficits of about $75 \%$ compared with normal years, due both to a decrease in annual supply of $5.5 \%$ and an increase in demand from irrigation of some $15 \%{ }^{(14)}$. Given the impact of droughts over the last fifteen years, one can anticipate that the effects of climate change on the frequency of such events over the coming decades will involve enormous risks for water resource management and the satisfaction of needs.

\section{An agricultural region particularly vulnerable to climate change}

\section{Water shortages issues for agriculture in northern China}

The increasing scarcity of water, and competition from other economic sectors, put the irrigation capacity of the northern regions under great pressure. Cereal production, a sector heavily dependent on irrigation, is thus faced with an unprecedented challenge. In the $3 \mathrm{H}$ basin, agriculture is the principal consumer of water, but the sector also bears the brunt of most of the shortage since it accounts for more than $80 \%$ of the region's total deficit. Every year more than a quarter of the demand from agriculture is not met. In drought years, deficits for crops are roughly doubled and reach 62 billion cubic metres. Agriculture, whose needs increase during drought years while availability falls, ends up acting as a buffer to ensure that the needs of other sectors are met. In those years, agriculture is often sacrificed to limit water shortage increases in industry and domestic households.

The structural inadequacy of water supply and the increased frequency of droughts are substantially reducing the poten-

13. Ying Aiwen, Impact of Global Climate Change on China's Water Resources, Environmental Monitoring and Assessment, 61(1), 2000, pp. 187-191.

14. World Bank, China Agenda for Water Sector Strategy for North China, op. cit.. 

Graph 4. Distribution of irrigation possibilities in the $3 \mathrm{H}$ basin according to climatic conditions, projected to 2030

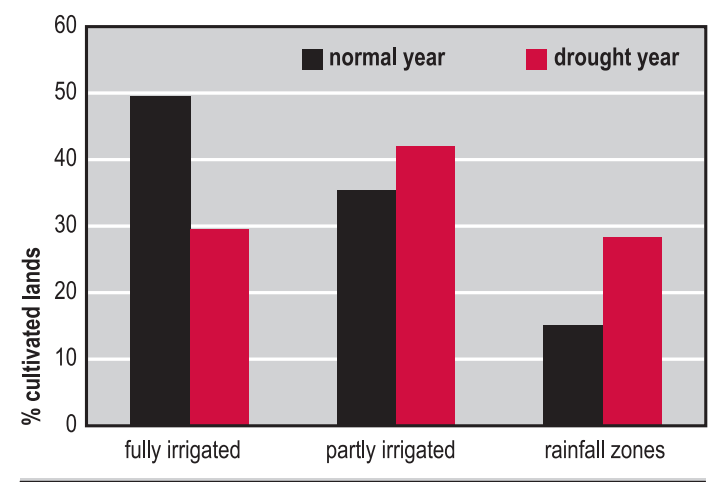

Source: World Bank, 2002.

desertification. Vulnerability indicators based on the agricultural context and the socio-economic capacity to adapt show that among the thirty Chinese provinces, Shanxi, Inner Mongolia, Gansu, Hebei and Ningxia would be especially at risk and the least able to adapt to climate change ${ }^{(19)}$. In northern China, the most sensitive regions are thus also the most vulnerable and comprise the greater part of the 3-H basin.

\section{An unfavourable context of inter-sectoral competition for water}

The context of inter-sectoral competition for water in which climate change is taking place is an essential consideration in anticipating the risks for agriculture. In the $3-\mathrm{H}$ region, $80 \%$ of cultivated land is irrigated and these water flows are a vital factor in the system of double annual harvests which characterises the region and which underpins its status as China's cereal granary. Agriculture is the main consumer of water but it is not a priority sector. Water allocation increasingly favours industrial and domestic needs, especially during periods of drought. Thus, reductions in water availability due to climate change place a double burden on agriculture: its need for water grows as drought conditions worsen, while at the same time reductions in supply mean that its share of the water available will be correspondingly less. Variations in irrigation according to climatic conditions illustrate the situation well: droughts reduce the area of cultivated land totally irrigated by 20 points and increase the rainfall dependent areas and those partly under irrigation by 13.5 and 6.5 points respectively (Graph 4). To the extent that climate change will increase the frequency of drought years, the risks for irrigation capacity seem enormous.
ZWhile it is conceivable that adaptation policies for water supply and demand can be found for the north of the country, it is clear that agriculture will have to rely very largely on its own capacity to use water more economically. The potential for water saving in this sector is sizeable in the short term, but it could, nonetheless, be limited by climate change. As far as south-north transfers are concerned, which is the principal source of future additional water for north China, there is little cause for optimism because, like all the largescale projects planned or under construction, the aim is not to increase irrigation ${ }^{(20)}$. At best, agriculture would only receive a residual part of the transfers, priority always being given to urban needs ${ }^{(21)}$. Irrigation's marginal status in water allocation seems unavoidable: the economic gain from each unit of water consumed by agriculture is small compared with other sectors, and the low price paid for irrigation water, compared with water for industrial and domestic uses, encourages local administrators to divert water from agriculture to other sectors ${ }^{(22)}$. In this context, climate change could exacerbate inter-sectoral conflicts about water which have already turned violent at times ${ }^{(23)}$.

\section{Impact on agricultural yields}

Models indicate that climate change will have a generally negative effect on Chinese agricultural performance even though new areas in the extreme north of the country could become suitable for agriculture. The three principal crops, wheat, rice and maize, will see their yields reduced by an average of $10 \%$ during the first half of the twenty-first century. Increases in temperatures will shorten the growth periods of crops and the nutritional quality of cereals, but the main effects on agriculture will come from increasing droughts and water shortages. It is anticipated that wheat yields will decrease by an average of $4 \%$ in the irrigated zones to $16 \%$

19. Lin Erda, "Agricultural Vulnerability and Adaptation to Global Warming in China," Water, Air, and Soil Pollution, $\mathrm{n}^{\circ}$ 92, pp. 63-73, 1996

20. Hong Yang , Zehner A., "China's Regional Water Scarcity and Implications for Grain Supply and Trade," op. cit.

21. ZSN, Chinese Water Conservation Yearbook, Water and Electricity Publishing House, Beijing, 1997.

22. The economic benefits of inter-regional transfers through the central route are estimated at 0.99 yuan per cubic metre of water in urban and industrial sectors as against 0.56 for agriculture. For the same project, the average price of water provided to industry is thought to be 0.31 yuan per cubic metre and 0.06 yuan for agriculture (ZSN, Chinese Water Conservation Yearbook, op. cit.)

23. For example, on 6 July 2000, thousands of farmers from the northern plains clashed with police, reacting angrily to a government project which allocated water from certain dams to cities and industry rather than irrigation. 


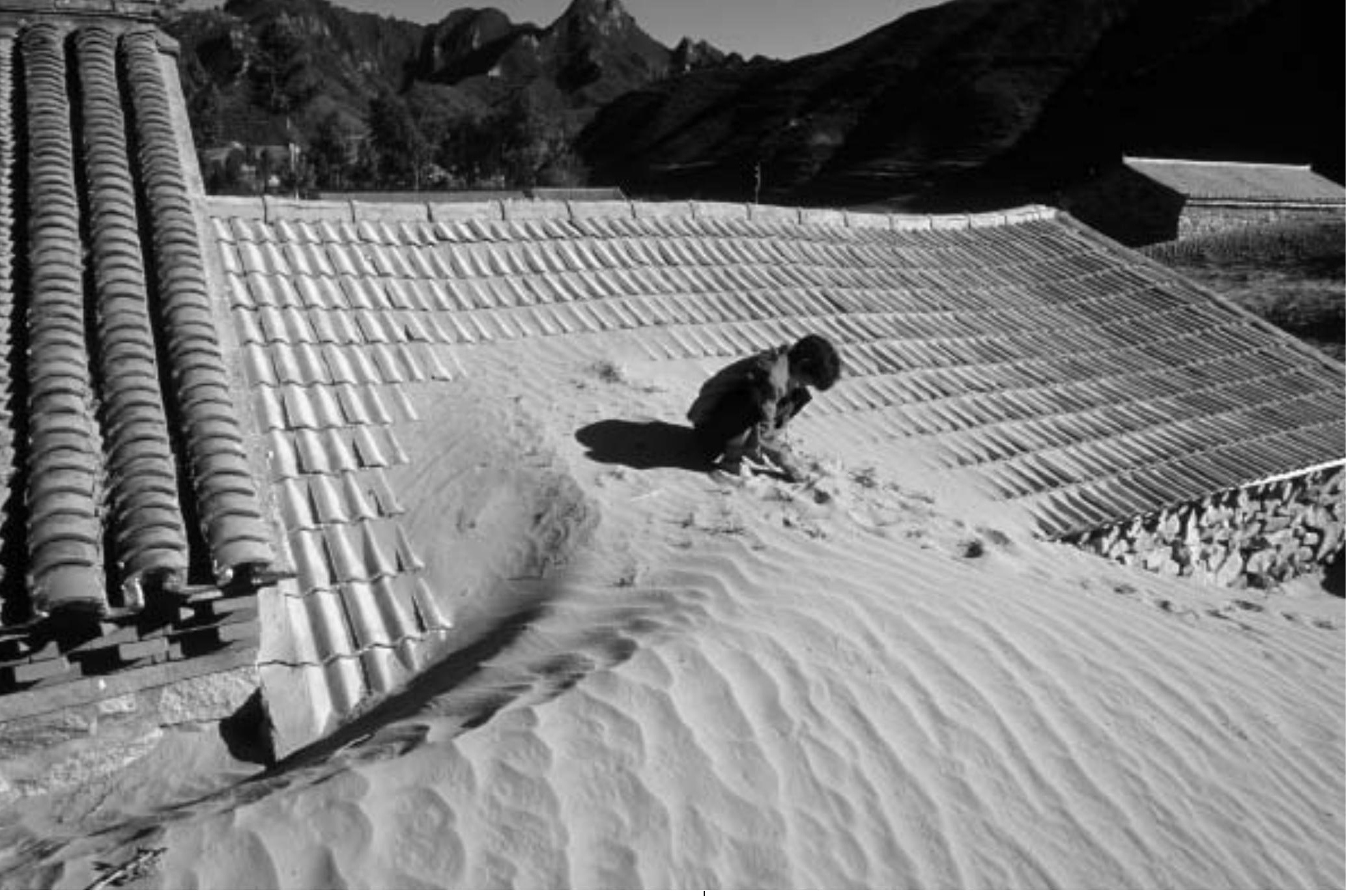




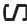

by the central government as in the case of the 2006 drought which saw nearly 30,000 peasant farmers move from Chongqing and Chengdu to Xinjiang.

\section{Food self-sufficiency versus importation of virtual water}

Finally, one can view the risks to agriculture of climate change in the context of the uncertainty surrounding future cereal production and China's capacity to meet its own needs. The issue of food security and the potential impact of China's entry into world agricultural markets are burning questions. In 1994, L. Brown, in an article entitled "Who will feed China?" highlighted the issue and sparked a lively debate. His analysis is simple: China's decreasing capacity to produce cereals in consequence of the loss of arable lands that follow industrialisation and growing water deficits will require it to import enormous quantities of cereals ${ }^{(27)}$. The consequences of this would be significant price increases on world markets and a growing threat to the food security and political stability of developing countries. Climate change could accelerate these trends, exacerbating water deficits and adding greatly to the loss of arable lands through increased desertification.

This need for large-scale reliance on world markets to meet cereal requirements has not yet arisen. Nevertheless, falls in production between 1999 and 2003 could be sustained, without any real increase in imports, only through repeated calls on cereal stocks built up between 1996 and 2002 to make up for an annual deficit of 30 million tonnes. If, as is likely, climate change reduces production capacity, it does not necessarily follow that an agricultural crisis in China will be likely. The effects on world markets would depend more specifically on the strategies China adopted to respond to the water crisis. The physical capacity to produce the cereals China needed to feed itself would still be sufficient, but the rational response would not necessarily make maximum use of land and water resources ${ }^{(28)}$.

It could in fact become economically efficient to have recourse to world markets and participate in "virtual water trade," ${ }^{229}$ by importing water in the form of cereals. At present, one cubic metre of water is needed to produce one kilogram of cereals. If ten million tonnes of cereals were imported rather than produced in the northern plains, close to ten billion cubic metres of water would be saved. The limited water and land resources could then be used more efficiently, planting different crops with a high value-added component, for example, with a view to export possibilities. Given
China's increasing comparative disadvantage in cereal production and its progressive integration into the world economy, larger cereal imports seem inevitable. Importing virtual water would seem to be an appropriate strategy not only because it would significantly reduce stress on northern China's water resources, but also because it would be in keeping with the direction in which the Chinese economy is moving. It remains to be seen if the China of market socialism will be prepared to challenge the Maoist regime's principle of self-sufficiency in food.

The fact remains, however, that there are continuing uncertainties surrounding trends in the world's capacity for cereal production, particularly in a context of climate change. The effects of such a strategy on the ability of the poorest developing countries to purchase the cereals they need on world markets may not all be benign.

\section{Conclusion}

Climate change poses an unprecedented challenge to the water and agricultural systems of northern China. Although the balance has often been upset, expected rises in temperatures could accelerate the existing situation of worsening water deficits and the deterioration of arable lands. In addition, there are risks of flooding in coastal cities threatened by rising sea levels, and the enlargement of areas affected by certain vector diseases such as malaria. The early implementation of appropriate response measures to respond to the new situation, which in the case of agriculture would involve water policies structured around the scarcity of the resource, could reduce these risks and at the same time deal with present problems. In this context, the international community should, while striving to reduce greenhouse gas emissions, formulate proposals to help developing countries adapt to the changing circumstances. $\bullet$

\section{- Translated by Peter Brown}

27. Brown's analysis is consistent with other studies, in particular those of the World Bank and the United States Department of Agriculture.

28. G. K. Heilig, China Food, Can China Feed Itself?, IIASA, Laxenburg, 1999.

29. T. Allan, Water, Peace and the Middle East: Negotiating Water in the Jordan Basin, IB Tauris, London, 1996. 